\title{
PRODUKTIVITAS BURUH TANI PENYADAP KARET RAKYAT DAN STRUKTUR PENDAPATAN RUMAH TANGGANYA (DESA AIR SEKAMANAK KECAMATAN KETAHUN KABUPATEN BENGKULU UTARA)
}

\section{(RUBBER TAPPERS PRODUCTIVITY AND THEIR HOUSEHOLDS INCOME STRUCTURE (CASE IN AIR SEMANAK SUBDISTRICT OF KETAHUN, DISTRICT OF NORTH BENGKULU)}

\author{
Ridlo Syahfrudin, Ketut Sukiyono, dan Ellys Yuliarti \\ Jurusan Sosial Ekonomi Pertanian \\ Fakultas Pertanian Universitas Bengkulu
}

\begin{abstract}
The research was conducted in the Air Sekamanak village ketahun in North Bengkulu. The research location is determined purposively with consideration the village population moyority are farming rubber $75 \%$. The purpose of this study to: 1) Estimate the level of productivity of rubber tappers, 2) Investigate the structure of rubber tappers household income. The object of research is the variables that relate to activities that taptime employment, production, costs and revenues. The results of this study with the conclusions 1) Average labor productivity of agricultural workers in the rubber tappers of the Air Sekamanak village 3,822 Kg/wacth. 2) The average income of households in the Air Sekamanak village Rp 1.9466.490,476/month. The average income derived from farm laborers for the rubber tappers $R p$ 1.720.740,476/farming/month its contribution to household income by $88,402 \%$. While the average income derived from activities outside of tapping rubber laborers $\mathrm{Rp} 225.750 /$ month. This means that contribution to household income is about $11,598 \%$.
\end{abstract}

Key words: Productivity, Farm workers, Income Structure

\section{PENDAHULUAN}

Komoditi karet memiliki potensi yang cukup besar untuk dikembangkan di Provinsi Bengkulu. Perkebunan karet berperan penting dalam pembangunan pertanian di Provinsi Bengkulu, terutama sebagai penghasil devisa, penyerapan tenaga kerja local, sumber pendapatan masyarakat dan kontribusi terhadap Produk Domestik Regional Bruto (PDRB). Kontribusi subsektor perkebunan karet terhadap PDRB Provinsi Bengkulu sebesar 2,21 persen dari kontibusi subsektor perkebunan terhadap PDRB Provinsi Bengkulu sebesar 12,18 persen. Luas areal perkebunan karet di Provinsi Bengkulu adalah 78.182 hektar. Terdapat 3 jenis perkebunan karet yang ada di Provinsi Bengkulu, yaitu 
Perkebunan Rakyat (PR), Perkebunan Besar Negara (PBN) dan Perkebunan Besar Swasta (PBS). Sebagian besar komoditas tanaman karet di Provinsi Bengkulu merupakan usaha Perkebunan Rakyat (PR), yaitu dengan luas lahan 60.352 hektar.

Tabel 1. Luas Areal dan Produksi Karet Provinsi Bengkulu

\begin{tabular}{clcccccc}
\hline \multirow{2}{*}{ No } & \multirow{2}{*}{ Kabupaten/Kota } & \multicolumn{3}{c}{ Luas (Ha) } & \multicolumn{3}{c}{ Produksi (ton/thn) } \\
\cline { 3 - 8 } & & PR & PBN & PBS & PR & PBN & PBS \\
\hline 1 & Bengkulu utara & 24.537 & 6.375 & 6.146 & 29.022 & 9.302 & 7.922 \\
2 & Bengkulu Selatan & 4.073 & - & - & 3.285 & - & - \\
3 & Rejang lebong & 3.762 & - & - & 2.696 & - & - \\
4 & Seluma & 17.397 & 4.725 & - & 19.325 & 6.562 & - \\
5 & Kaur & 979 & - & - & 835 & - & - \\
6 & Muko-muko & 8.813 & - & 2.034 & 9.336 & - & 339 \\
7 & Lebong & 706 & - & - & 385 & - & - \\
8 & Kepahiang & 34 & - & - & 5 & - & - \\
9 & Kota Bengkulu & 51 & - & - & 51 & - & - \\
\hline JUMLAH TOTAL & 60.352 & 11.100 & 8.180 & 64.940 & 15.864 & 8.261 \\
\hline
\end{tabular}

Sumber : Badan Pusat Statistik Provinsi Bengkulu, 2009.

Kabupaten Bengkulu Utara merupakan daerah dengan luas lahan yang digunakan atau dimanfaatkan sebagai lahan perkebunan karet dan produksi yang dihasilkan tergolong tinggi di bandingkan dengan kabupaten lainnya. Daerah ini mendominasi luas lahan perkebunan karet rakyat yaitu, 24.537 hektar atau sebesar 40,72 \% dari keseluruhan perkebuna karet rakyat yang ada di Proviasi Bengkulu. Selain sebagai daerah yang mempunyai luas lahan perkebunan karet rakyat yang luas tetapi juga dapat menghasilkan produksi karet yang tinggi yaitu, 29.022 ton/thn atau rata-rata produksi sebesar 1,183 ton/Ha/thn.

Potensi luas lahan Perkebunan Karet Rakyat (PR) Bengkulu Utara merupakan sumber kesempatan kerja bagi masyarakat. Usahatani karet ini mampu menyerap tenaga kerja sebanyak 37.660 jiwa. Dari jumlah tersebut tenaga kerja yang tidak memiliki lahan/kebun karet bekerja sebagai buruh tani penyadap karet. Buruh tani penyadap karet bekerja kerena petani karet yang tidak mampu lagi atau tidak mempunyai waktu untuk melakukan kegiatan menyadap, maka mereka mempekerjakan seseorang untuk bekerja sebagai buruh dalam kegiatan menyadap karet.

Salah satu daerah di Kabupaten Bengkulu Utara yang masyarakatnya membudidayakan komoditi karet adalah Desa Air Sekamanak. Desa Air Sekamanak merupakan daerah dengan mayoritas masyarakatnya bermata pencaharian sebagai petani karet dengan luas lahan Perkebunan Rakyat (PR) 900 
hektar dan Perkebunan Inti Rakyat (PIR) dengan luas lahan 1300 hektar. Penduduk yang mata pencahariannya berasal dari kegiatan usahatani karet di Desa Air Sekamanak berjumlah 698 jiwa. Oleh karena itu penelitian ini secara khusus mempelajari produktivitas buruh tani penyadap karet rakyat dan struktur pendapatan rumah tangganya di Desa Air Sekamanak Kecamatan Ketahun Kabupaten Bengkulu Utara.

Banyak penelitian telah dilakukan terkait dengan tenaga kerja, khususnya produktivitas tenaga kerja dan faktor yang mempengaruhinya. Salah satunya adalah Wayan dan Suryadi (2004). Mereka meneliti tentang ekonomi tenaga kerja pertanian dan implikasinya dalam peningkatan produksi dan kesejahteraan buruh tani. Kesempatan kerja sektor pertanian, posisinya masih dominan dengan status pekerjaan buruh tani. Permasalahan tenaga kerja pertanian adalah produktivitas rendah. Rendahnya produktivitas kerja sektor pertanian dipengaruhi oleh tingkat upah yang rendah. Produktivitas buruh tani dapat ditingkatkan melalui antara lain perbaikan tingkat upah, pendidikan dan pembinaan keterampilan tenaga kerja. Penelitian lain dilakukan oleh Iskandar (2002) dan Akmal (2010). Iskandar meneliti etos kerja, motivasi dan sikap inovatif terhadap produktivitas petani. Sementara Akmal meneliti peranan upah, motivasi dan kepuasan dalam meningkatkan kinerja.

Penelitian tentang produktivitas tenaga kerja penyadap karet dilakukan oleh Widodo (2003). Widodo menyimpulkan bahwa faktor jumlah tanggungan keluarga, masa kerja, dan motivasi kerja memliliki hubungan nyata dengan produktivitas tenaga kerja penyadap karet dan menyadap merupakan mata pencaharian utama. Sementara itu, Nurmanaf (2003) meneliti peranan sektor non pertanian terhadap pendapatan rumah tangga petani berlahan sempit. Hasil penelitian Nurmanaf menyimpulkan bahwa struktur pendapatan rumah tangga petani berlahan sempit mempunyai perbedaan yang disebabkan perbedaan sumber pendapatan.

Dari diskusi di atas, dapat disimpulkan bahwa hasil-hasil penelitian yang sudah pernah dilakukan melihat produktivitas tanaga kerja tidak terlepas dari pengaruh upah, motivasi kerja, masa kerja, tanggungan keluarga dan keteranpilan yang dimiliki oleh pekerja. Kekurangan penelitian sebelumnya tidak melihat waktu yang dipergunakan untuk memperoleh hasil yang didapat dari kegiatan yang dilakukan. Untuk itu, tujuan penelitian ini adalah untuk mengetahui seberapa besar tingkat produktivitas buruh tani penyadap karet dan stuktur pendapatan rumah tangga buruh tani penyadap karet.

\section{METODOLOGI PENELITIAN}

\section{Metode Penentuan Lokasi dan Responden}

Penelitian ini dilakukan di Desa Air Sekamanak Kecamatan Ketahun Kabupaten Bengkulu Utara. Penentuaan lokasi penelitian dilakukan secara sengaja (purposive) dengan pertimbangan bahwa desa tersebut merupakan desa 
yang moyoritas penduduknya adalah berusahatani karet yaitu, 75\%. Potensi lahan yang luas yaitu, 2.200 Ha mampu menyerap tenaga kerja 698 jiwa. Dari serapan tenaga kerja tersebut, berdasarkan morfologi desa pada jenis pekerjaan terdapat penduduk yang bekerja sebagai buruh tani penyadap karet sebanyak 28 jiwa.

Metode pengambilan sample yang dilakukan dengan "Metode Sensus" yaitu, dengan melakukan pendataan seluruh anngota populasi dilokasi penelitian. Karena jumlah buruh tani di daerah penelitian ini 28 responden sehingga semua buruh tani karet akan di jadikan sample dalam penelitian ini.

\section{Metode Analisis Data}

Analisis produktivitas kerja penyadap karet dihitung dengan rumus sebagai berikut

$$
\mathbf{N P}=\frac{Y}{L}
$$

dimana NP adalah Nilai produktivitas kerja $(\mathrm{kg} / \mathrm{jam}), \mathrm{Y}$ adalah jumlah hasil sadapan (kg), dan L adalah jumlah jam kerja (jam)

Sementara itu, pendapatan buruh tani penyadap karet ini dilakukan analisis pendapatan dengan persamaan matematik sebagai berikut (Soekartawi (1995):

$$
\begin{aligned}
& \mathbf{P d}=\text { TR }- \text { TC } \\
& \text { TR }=\text { Y } . \text { Py }
\end{aligned}
$$

dimana Pd adalah Pendapatan (Rp/Bln), TR adalah Total penerimaan (Rp/ Bln), TC adalah Biaya dalam proses penyadapan ( $\mathrm{Rp} / \mathrm{Bln}), \mathrm{Y}$ adalah Jumlah hasil sadapan $(\mathrm{Kg} / \mathrm{Bln})$, dan Pyadalah Harga karet $(\mathrm{Rp} / \mathrm{Kg})$

Sedangkan untuk mengetahui pendapatan yang berasal dari luar kegiatan menyadap dan pendapatan masing-masing anggota keluarga rumah tangga buruh tani penyadap karet (Rp/Bln), dengan melakukan interview pada waktu mengisi kuesioner (daftar pertanyaan) langsung kepada responden.

Struktur pendapatan rumah tangga di analisis dengan melihat kontribusi masing-masing anggota keluarga rumah tangga dari jenis pekerjaan yang di jalani. Kontribusi pendapatan merupakan presentase pendapatan yang diterima dari masing-masing sumber terhadap total pendapatan keluarga.

$$
\mathbf{K}_{\mathrm{ij}}=\frac{P d_{i j}}{P d_{\text {total }}} 100 \%
$$

dimana $\mathrm{K}_{\mathrm{ij}} \quad=$ Kontribusi pendapatan $(\%), \mathrm{Pd}_{\mathrm{ij}} \quad=$ Pendapatan individu dari sumber ke-i dari pendapatan rumah tangga ke-j., $\mathrm{Pd}_{\text {total }}=$ Total pendapatan keluarga. 


\section{HASIL DAN PEMBAHASAN}

\section{Karakteristik Responden}

Karakteristik responden ialah faktor-faktor yang ada dalam diri responden untuk mengetahui kondisi serta keadaan yang sebenarnya dari responden yang akan diamati. Dalam penelitian ini karakteristik yang diamati meliputi umur, jumlah tanggungan keluarga, luas lahan, tingkat pendidikan dan pengalaman usahatani. Karakteristik petani karet di Desa Air Sekamanak Kabupaten Bengkulu Utara dapat dilihat pada Tabel 2.

Tabel 2 Karakteristik Buruh Sadap Karet di Desa Air Sekamanak Kabupaten Bengkulu Utara

\begin{tabular}{|c|c|c|c|c|}
\hline No & Uraian & $\begin{array}{c}\text { Persentase } \\
(\%)\end{array}$ & Kisaran & Rata-rata \\
\hline \multirow[t]{4}{*}{1} & Umur (Th) & & \multirow{4}{*}{$18-34$} & \multirow{4}{*}{24,821} \\
\hline & Muda $\quad(<23)$ & 28,572 & & \\
\hline & Sedang $(23-28)$ & 60,714 & & \\
\hline & Tua $\quad(>28)$ & 10,714 & & \\
\hline \multirow[t]{3}{*}{2} & Jumlah Tanggungan Keluarga & & \multirow{3}{*}{$0-3$} & \multirow{3}{*}{1,036} \\
\hline & Punya tanggungan keluarga & 37,931 & & \\
\hline & Tidak punya & 58,621 & & \\
\hline \multirow[t]{4}{*}{3} & Tingkat Pendidikan (Th) & & \multirow{4}{*}{$9-12$} & \multirow{4}{*}{10,714} \\
\hline & Rendah $(<10)$ & 42,857 & & \\
\hline & Sedang (10-11) & 0 & & \\
\hline & Tinggi $(>11)$ & 57,143 & & \\
\hline \multirow[t]{4}{*}{4} & Pengalaman Buruh Sadap(Th) & & \multirow{4}{*}{$1-8$} & \multirow{4}{*}{4,429} \\
\hline & Sebentar $(<3)$ & 21,429 & & \\
\hline & Sedang $(3-5)$ & 42,857 & & \\
\hline & Lama $\quad(>5)$ & 35,714 & & \\
\hline
\end{tabular}

Sumber : Data primer, 2011

Berdasarkan hasil penelitian yang didapat dari 28 responden menunjukkan kisaran umur buruh sadap dari 18 sampai 34 tahun, dengan ratarata umur buruh sadap di daerah tersebut adalah 24,821 tahun. Pada jenjang umur yang dimiliki oleh petani karet yang berkisar antara 18-34 tahun, menunjukkan bahwa seratus persen buruh sadap tergolong pada usia produktitif. Umur berkaitan erat dengan semangat kerja, kondisi fisik seseorang, dan tenaga dalam melakukan kegiatan usahatani. Hal ini sesuai dengan pendapat Sahara (2004) umur produktif berada dalam kisaran umur antara 20 50 tahun, Umur muda dan tingkat pendidikan yang tinggi memungkinkan petani lebih dinamis dan lebih dapat menerima inovasi baru. Dengan kondisi tersebut petani mampu mengelola usahatani seoptimal mungkin dengan curahan tenaga fisik yang tersedia. Oleh karena itu pada usia produktif ini buruh sadap diharapkan dapat mengelola usahataninya secara maksimal sehingga produksi yang didapat nantinya akan optimal. Rata-rata umur buruh 
sadap termasuk dalam katagori usia tua sebesar 10,714 persen dan 28,572 persen dalam katagori usia muda, sedangkan yang termasuk dalam katagori sedang sebesar 60,714 persen.

Jumlah tanggungan keluarga erat hubunganya dengan jumlah tanggungan buruh sadap sebagai kepala keluarga, terutama anggota keluarga yang non produktif. buruh sadap yang mempunyai tanggungan keluarga lebih banyak harus berusaha lebih baik lagi dalam berusahatani guna mampu memenuhi kebutuhan keluarga. Hasil penelitian menunjukkan bahwa jumlah tanggungan keluarga buruh sadap di daerah penelitian berkisar antara 0-3 orang, dengan rata-rata jumlah tanggungan keluarga 1,036. Jumlah tanggungan keluarga dengan persentase terbesar terletak pada kisaran 1-2 dengan besar 57,143 persen, sedangkan jumlah tanggungan keluarga yang terkecil yaitu $<1$ dan $>2$ sebesar 39,286 persen dan 3,571 persen. Jumlah tanggungan keluarga yang dibebankan kepada kepala keluarga biasanya terdiri dari istri, anak-anak, orang tua dan anggota keluarga lainnya selain kepala keluarga. Jumlah tanggungan keluarga adalah salah satu yang mempengaruhi pada tingkat pengeluaran dalam memenuhi kebutuhan keluarga, semakin besar jumlah tanggungan keluarga maka akan semakin besar pula pengeluaran dalam memenuhi kebutuhan keluarga dan sebaliknya'

Lahan merupakan unsur pokok dalam berusahatani selain modal, tenaga kerja dan manajemen. Luas lahan merupakan salah satu faktor produksi penting semakin luas lahan yang dikerjakan oleh buruh sadap maka produksi yang diharapkanpun akan semakin besar dan pada akhirnya akan berpengaruh terhadap pendapatan yang diterima oleh buruh sadap. Sejalan dengan yang di kemukakan oleh Soekartawi (2002), bahwa tanah merupakan salah satu modal pokok dalam berusahatani. Semakin luas lahan garapan untuk berusahatani maka diharapkan semakin besar produksi yang di hasilkan. Berdasarkan luas lahan yang dikerjakan oleh buruh sadap di daerah penelitian dengan rata-rata luas lahan sebesar $2 \mathrm{Ha}$.

Pendidikan adalah salah satu faktor penunjang keberhasilan dalam melaksanakan usahataninya, karena tingkat pendidikan sangat mempengaruhi kemampuan buruh sadap dalam bertindak dan cara pengambilan keputusan, seperti menyerap suatu inovasi dalam melakukan penyadapan. Hamidun (2007), mengatakan bahwa tingkat pendidikan harus selalu dikembangkan baik melalui jalur pendidikan formal maupun informal. Diasumsikan makin tinggi tingkat pendidikan sesorang, makin tinggi pula tingkat produktivitas yang mungkin dapat dicapainya. Karena setiap penggunaan teknologi hanya akan dapat kita kuasai dengan pengetahuan, keterampilan dan kemampuan yang handal. Dari Tabel 2 dapat dilihat bahwa rata-rata tingkat pendidikan yang ditempuh buruh sadap di daerah penelitian tergolong sedang yaitu 10,714 tahun. Persentase tingkat pendidikan buruh sadap terbesar berada pada tingkat pendidikan $>11$ tahun yaitu sebesar $57,143 \%$.

Hal ini dapat disimpulkan bahwa tingkat pendidikan buruh sadap pada daerah penelitian berada pada tingkat pendidikan sekolah menengah pertama. Dengan kondisi tingkat pendidikan tersebut, maka dapat disimpulkan bahwa 
tingkat pendidikan di Desa Air Sekamanak sudah baik, dan secara tidak langsung mempengaruhi pengetahuan dan tingkat adopsi inovasi buruh sadap yang berkaitan dengan proses penyadapan, sehingga mampu meningkatkan produktivitas kerja.

Pengalaman kerja adalah hasil penyerapan dari berbagai aktivitas indera kita, maka pengalaman kerja yang dimaksud disini dapat berupa kemahiran, ketangkasan, serta ketrampilan dalam menjalankan tanggung jawabnya atau pekerjaannya. Pengalaman menjadi buruh sadap karet akan mempengaruhi kemampuan dan ketepatan dalam melakukan proses penyadapan. Semakin berpengalaman buruh sadap akan cenderung belajar dari pengalaman sehingga ia memiliki gambaran tentang apa yang akan dilakukan dan mampu merespon setiap inovasi dengan pengalaman yang dimilikinya. Berdasarkan hasil penelitian, diketahui bahwa pengalaman buruh sadap berada pada kisaran antara 1-8 tahun. Dengan katagori yang termasuk mendominasi adalah pengalaman sedang sebesar 42,857 persen, sedangkan yang terkecil berada pada kategori sebentar dengan persentase 21,429 persen. Hasil penelitian menunjukkan bahwa rata-rata pengalaman buruh sadap di daerah penelitian adalah 4,429 tahun

Dalam penelitian ini yang menjadi pedoman untuk peranan pengalaman kerja dalam mencapai produktivitas kerja adalah senioritas (masa kerja). Dari pengalaman kerja akan dicapai suatu produktivitas kerja yang lebih optimal. Buruh sadap karet yang telah lama bekerja tentunya akan memiliki kematangan dalam pengambil keputusan yang akan dilakukan dan pengalaman yang didapat untuk membantu pemecahan masalah yang timbul, sehingga dapat terccapai keberhasilan dalam kegiatan penyadapan.

\section{Rata-rata Produktivitas kerja}

Nilai produktivitas kerja dihitung dengan membagikan rata-rata hasil sadapan dengan rata-rata jumlah jam kerja. Hasil sadapan, merupakan banyaknya getah karet yang mampu diperoleh oleh seorang penyadap (Kg/Ut/Bln).

Produktivitas kerja merupakan ukuran hasil kerja yang di lakukan. Semakin besar produktivitas kerja seseorang maka semakin besar hasil kerja yang di peroleh. Berdasarkan dari rincian di atas, produktivitas kerja buruh sadap kisaran antara 2,73-5,46 kg/jam. Dengan katagori produktivitas tinggi > 4,55 kg/jam yaitu 14,29 persen, katagori produktivitas sedang 3,64 kg/jam - 4,55 $\mathrm{kg} / \mathrm{jam}$ yaitu 35,71 persen dan katagori yang termasuk mendominasi adalah pada tingkat produktivitas kerja rendah $<3,64 \mathrm{~kg} / \mathrm{jam}$ yaitu sebesar 50 persen.

Dari rincian di atas, dapat disimpulkan bahwa waktu kerja yang di pergunakan oleh buruh sadap karet dan karakteristik responden yang terdiri dari umur, tanggungan keluarga, pendidikan dan pengalaman kerja tidak berpengaruh terhadap produktivitas kerja. Sehingga peningkatan produktivitas kerja hanya dapat dilakukan dengan meningkatkan produksi. Umur pohon karet di daerah penelitian yaitu rata-rata 25 tahun, pada umur tersebut bahwa 
produksi mulai menurun serta tanpa ada perlakuan pemupukan sehingga produksi yang di hasilkan rendah. Masih sulitnya akses barang-barang input seperti pupuk dan dengan harga pupuk yang tinggi membuat petani enggan memberi pupuk.

Tabel 8. Produktivitas Kerja Buruh Sadap Karet Desa Air Sekamanak Kecamatan Ketahun Kabupaten Bengkulu Utara.

\begin{tabular}{|c|c|c|c|c|c|}
\hline No & Uraian & Jumlah & Persentase $(\%)$ & Rata-rata & Kisaran \\
\hline \multirow{4}{*}{1} & Produksi (Kg/Ut/Bln) & & & & \multirow{4}{*}{$207-347$} \\
\hline & Rendah $(<254)$ & 14 & 50,00 & 238,93 & \\
\hline & Sedang (254-300) & 10 & 35,71 & 276,20 & \\
\hline & Tinggi $(>300)$ & 4 & 14,29 & 333,00 & \\
\hline \multirow{4}{*}{2} & Waktu Kerja (Jam) & & & & \multirow{4}{*}{$55-96$} \\
\hline & Sebentar $(<68,6)$ & 13 & 46,42 & 61,39 & \\
\hline & Sedang $(68,67-82,33)$ & 11 & 39,29 & 74,36 & \\
\hline & Lama $\quad(>82,33)$ & 4 & 14,29 & 93,00 & \\
\hline \multirow{4}{*}{3} & Produktivitas kerja (Kg/Jam) & & & & \multirow{4}{*}{$2,73-5,46$} \\
\hline & Rendah $(<3,64)$ & 14 & 50,00 & 3,24 & \\
\hline & Sedang $(3,64-4,55)$ & 10 & 35,71 & 4,09 & \\
\hline & Tinggi $(>4,55)$ & 4 & 14,29 & 5,23 & \\
\hline
\end{tabular}

Sumber : Data primer, 2011

Barani (2008), dari aspek produksi, produktivitas karet rakyat umumnya masih rendah yaitu antara 900-1.000 Kg/Ha/Tahun. Rendahnya produktivitas karet rakyat disebabkan petani tidak memberi pupuk pada tanaman karet dan sebagian besar tanaman yang sudah tidak produktif (tua/rusak). Umur produktif tanaman karet yaitu 15-25 tahun.

Efrida (2008), hasil penelitiannya menunjukkan bahwa rata-rata produktivitas kerja penyadap karet di Desa Tanobato Kecamatan Panyabungan Selatan Kabupaten Madina Sumatra Utara adalah sebesar 3,46 kg/jam. Dari hasil tersebut bahwa prodktivitas kerja di desa tanobato masih rendah berdasarkan pembanding dengan produktivitas kerja di PTPN III Sumatra Utara dengan produktivitas kerja sebesar $3,86 \mathrm{~kg} / \mathrm{jam}$.

Rata-rata hasil sadapan karet di Desa Air Sekamanak adalah sebesar 265,68 $\mathrm{Kg} / \mathrm{Ut} / \mathrm{Bln}$. Jam kerja, merupakan seluruh waktu yang digunakan oleh seorang penyadap karet untuk menghasilkan getah karet (Jam/Ut/Bln). Rata-rata waktu kerja yang dipergunakan oleh buruh sadap karet untuk mendapatkan hasil sadapan di Desa Air Sekamanak adalah 71 Jam/Ut/Bln. Rata-rata produktifitas kerja buruh sadap di Desa Air Sekamanak adalah 3,82 Kg/Jam.

Berdasarkan uraian diatas dapat di simpulkan bahwa produktivitas kerja di daerah penelitian sudah cukup baik. Karena produktivitas kerja di desa air sekamanak menunjukkan lebih tinggi di bandingkan dengan produktivitas kerja di desa tanobato atau hampir mendekati tingkat produktivitas kerja di PTPN III Sumatera Utara. 


\section{Penggunaan dan Biaya Dalam Proses Penyadapan}

Biaya dalam memperoleh hasil sadapan yang dihitung pada penelitian ini berupa biaya yang dikeluarkan dalam melakukan proses penyadapan dalam waktu satuan bulan. Perhitungan biaya dalam proses penyadapan karet ini dimaksudkan untuk mengetahui berapa besar tingkat pendapatan buruh sadap dari kegiatan penyadapan karet yang dilakukan. Biaya yang dikeluarkan oleh buruh sadap dalam penyadapan karet di daerah penelitian sifatnya ada yang merupakan biaya rill dan ada yang sifatnya biaya non-rill. Biaya rill yang dikeluarkan oleh buruh sadap berupa biaya angkut hasil sadapan dan biaya karung. Sedangkan yang non-rill yang dikeluarka adalah biaya penyusutan alat-alat pertanian, biaya angkut hasil sadapan dan biaya tenaga kerja. Biaya masing-masing tersebut dikelompokkan ke dalam biaya tetap dan biaya tidak tetap.

\section{Biaya Variabel}

Biaya variabel adalah biaya yang dikeluarkan dalam proses produksi yang sifat penggunaannya tidak tetap. Biaya variabel yang di keluarkan oleh buruh sadap dalam proses produksi adalah biaya angkut hasil sadapan dan karung. Rata-rata biaya angkut yang dikeluarkan adalah sebesar Rp $15.753,571 / \mathrm{UT} / \mathrm{Bln}$ dan biaya karung yang dikeluarkan adalah Rp 21.607,143/UT/Bln. Total biaya variabel rata- rata yang digunakan oleh buruh sadap dalam melakukan penyadapan karet adalah sebesar Rp 37.360,714/UT/Bln atau Rp 18.680,357/Ha/Bln.

Untuk menjual hasil sadapan yang berupa karet bekuan atau lumb ke pada pembeli seperti pedagang pengumpul tingkat desa, ada beberapa buruh sadap yang mengakut hasil panennya sendiri dan ada yang harus mengakut hasil panenya berupa getah yang sudah beku untuk di jual dengan beban biaya angkut dari kebun ke tempat pedagang pengumpul karet dan beban biaya ditanggung oleh bersama antara pemilik lahan dan penyadap karet dengan menggunakan jasa ojek. Besarnya biaya pengangkutan tersebut tergantung dari jarak dan kondisi jalan antara lahan kebun karet dengan tempat pengumpul karet. Biasanya alat angkut yang digunakan adalah sepeda motor, dengan tarif per kilogram.

Karung merupakan tempat atau wadah yang digunakan untuk menampung dari hasil sadapan. Banyak sedikitnya karung yang digunkan tergatung dengan banyak sedikitnya hasil sadapan yang diperoleh. Biaya karung ini ditanggung oleh penyadap karet yang di beli oleh penyadap karet di warung sekitar desa yang menjual kaarung atau di pasar yang letaknya diluar desa.

Tenaga kerja yang dipergunakan dalam proses penyadapan adalah tenaga kerja dalam keluarga. Standar upah tenaga kerja di daerah penelitian dengan waktu jam kerja 8 jam adalah sebesar Rp 35.000/hari/jam kerja. Rata-rata biaya tenaga yang dipergunakan dalam proses penyadapan sebesar Rp 770.000/Bln. 


\section{Biaya Tetap}

a. Biaya Penyusutan Alat

Alat-alat pertanian yang digunakan oleh buruh sadap dalam suatu kegiatan penyadapan umumnya tidak habis dipakai dalam satu kali penggunaan, untuk itu perlu dihitung biaya penyusutannya. Pada daerah penelitian jenis peralatan yang digunakan dalam penyadapan karet antara lain:, pisau sadap, pengasah, parang, dan sepatu. Perhitungan nilai penyusutan adalah harga awal dikurang dengan harga akhir dibagi umur ekonomis, dalam perhitungan tersebut harga akhir diasumsikan bernilai nol.

Tabel 3. Rata-rata Jumlah dan Biaya Penyusutan Peralatan Dalam Proses Penyadapan di Desa Air Sekamanak.

\begin{tabular}{llcr}
\hline No & \multicolumn{1}{c}{ Nama alat } & Jumlah biaya (Rp/UT/Bln) & \multicolumn{1}{c}{$\%$} \\
\hline 1 & Pisau sadap & $16.547,619$ & 52,182 \\
2 & Pengasah Pisau Sadap & $5.014,881$ & 15,814 \\
3 & Parang & $1.815,476$ & 5,725 \\
4 & Sepatu & $8.333,333$ & 26,279 \\
\hline & Jumlah & $31.711,310$ & 100,000 \\
\hline
\end{tabular}

Sumber: Olahan Data primer 2011

\section{Total Biaya Dalam Proses Penyadapan}

Biaya total yang dipergunakan dalam proses penyadapan merupakan penjumlahan semua biaya, baik biaya tetap (TFC) maupun biaya variabel (TVC) selama kegiatan penyadapan dalam satu bulan.

Tabel. 10. Total biaya produksi rata-rata dalam proses penyadapan

\begin{tabular}{|c|c|c|c|}
\hline Uraian & $\mathrm{Rp} / \mathrm{Bln}$ & $\mathrm{Rp} / \mathrm{Ha}$ & $\%$ \\
\hline \multicolumn{4}{|l|}{ Biaya Variabel (VC) } \\
\hline 1. Biaya angkut & $15.753,571$ & $7.876,786$ & 1,88 \\
\hline 2. Biaya karung & $21.607,143$ & $10.803,571$ & 2,58 \\
\hline 3. biaya Tenaga Kerja & $7770.000,000$ & $385.000,000$ & 91,77 \\
\hline \multicolumn{4}{|l|}{ Biaya Tetap (FC) } \\
\hline Biaya penyusutan alat & $31.711,309$ & $15.855,655$ & 3,78 \\
\hline Jumlah & $839.072,024$ & $419.536,012$ & 100,000 \\
\hline
\end{tabular}

Sumber: Olahan Data primer 2011

\section{Rata-rata Hasil Sadapan, Penerimaan, dan Pendapatan Buruh Sadap}

Hasil sadapan yang dihasilkan dari penyadapan karet adalah dalam bentuk karet bekuan atau lump. Rata-rata hasil sadapan karet di Desa Air Sekamanak adalah sebesar 265,679 Kg/Ut/Bln. Hasil sadapan karet 
mempengaruhi penerimaan petani dimana jumlah penerimaan yang didapat adalah jumlah hasil sadapan yang diterima oleh petani dengan satuan kilogram (Kg) dikalikan dengan harga jual karet pada saat itu. Rata-rata harga penjualan karet dalam sebulan dari setiap minggunya adalah Rp 13.500/Kg/Ut.

Tabel 11. Rata - Rata Pendapatan Buruh Sadap Karet Di Desa Air Sekamanak

\begin{tabular}{|c|c|}
\hline Jenis & nilai \\
\hline Hasil Sadapan $(\mathrm{Kg})$ & 265,679 \\
\hline Penerimaan (Rp/Bln) & $3.579 .625,000$ \\
\hline Penerimaan Pemilik Kebun(Rp/Bln) & $1.789 .812,500$ \\
\hline Penerimaan Buruh Sadap (Rp/Bln) & $2.559 .812,500$ \\
\hline - $\quad$ Penerimaan bagi hasil (Rp/Bln) & $1.789 .812,500$ \\
\hline - $\quad$ Penerimaan upah TK (Rp/Bln) & $770.000,000$ \\
\hline - $\quad$ Total Biaya Buruh sadap (Rp/Bln) & $839.072,024$ \\
\hline Pendapatan Buruh Sadap (Rp/Bln) & $1.720 .740,476$ \\
\hline
\end{tabular}

Sumber : Data Primer Diolah, 2011

Rata-rata penerimaan hasil sadap karet di Desa Air Sekamanak adalah Rp 3.579.625/Ut/Bln. Karena sistem upah buruh sadap di desa air sekamanak dengan sistem bagi hasil maka, masing-masing bagian antara pemilik lahan dan penyadap karet mendapat setengah bagian $(50 \%)$ dari hasil penjualan adalah sebesar Rp 1.789.812,500/Ut/Bln. Penerimaan buruh sadap dari upah sebagai tenaha kerja sebesar 770.000,000/Ut/ Bln.

Pendapatan buruh sadap adalah selisih antara total penerimaan dengan total biaya yang dikeluarkan. Rata-rata penerimaan buruh sadap sebesar Rp 2.559.812,500/Ut/Bln sedangkan biaya yang dikeluarkan sebesar Rp 839.072,024/Ut/Bln. Rata-rata pendapatan buruh sadap karet di Desa Air Sekamanak sebesar Rp 1.720.740,476/Ut/Bln.

\section{Pendapatan di luar kegiatan menyadap}

Pendapatan yang berasal dari luar kegiatan menyadap adalah pendapatan yang diterima oleh penyadap dari kegiatan selain menyadap karet ( $\mathrm{Rp} / \mathrm{Bln})$. Pendapatan rumah tangga yang berasal dari selain kegiatan menyadap pada umumnya tidaklah berasal dari satu sumber saja, tetapi dapat berasal dari dua atau lebih sumber pendapatan. Hal ini mengandung pengertian bahwa setiap anggota rumah tangga melakukan usaha atau bekerja untuk memenuhi kebutuhan rumah tangganya.

Kegiatan usaha atau pekerjaan di Desa Air Sekamanak yang berasal diluar kegiatan menyadap terdiri dari kegiatan ojek karet, penerangan (PLTD) dan bengkel. Rata-rata pendapatan yang berasal dari luar kegiatan menyadap karet di desa air sekamanak adalah sebesar Rp 225.750 / Bln. 


\section{Struktur Pendapatan Buruh Tani Penyadap Karet}

Kontribusi pendapatan adalah umtuk mengetahui berapa besarkah sumbangan pendapatan terhadap pendapatan keluarga. Nilai kontribusi pendapatan buruh sadap terhadap pendapatan keluarga adalah membagikan pendapatan buruh sadap dengan total pendapatan keluarga di kalikan seratus persen. Nilai kontribusi pendapatan yang berasal dari luar kegiatan buruh sadap terhadap pendapatan keluarga adalah membagikan total pendapatan keluarga selain dari buruh sadap dengan total pendapatan keluarga di kalikan seratus persen. Kontribusi pendapatan buruh sadap karet terhadap total pendapatan keluarga memberikan kontribusi yang besar $(88,402 \%)$ dibandingkan kontribusi yang berasal dari pendapatan keluarga yang berasal dari selain buruh sadap $(11,598 \%)$.

Tabel 12. Rata-Rata Total Pendapatan dan Kontribusi Pendapatan buruh sadap di Desa Air Sekamanak

\begin{tabular}{lcc}
\hline \multicolumn{1}{c}{ Jenis } & $\begin{array}{c}\text { Per Usahatani } \\
(\mathrm{Rp} / \mathrm{Ut} / \mathrm{Bln})\end{array}$ & $\begin{array}{c}\text { Kontribusi } \\
\text { Pendapatan }\end{array}$ \\
\hline $\begin{array}{l}\text { Pendapatan buruh sadap } \\
\begin{array}{l}\text { Pendapatan keluarga selain dari buruh } \\
\text { sadap }\end{array}\end{array}$ & $\begin{array}{r}1.720 .740,476 \\
225.750,000\end{array}$ & 11,598 \\
\hline Total Pendapatan Keluarga & $1.946 .490,476$ & 100,000 \\
\hline
\end{tabular}

Sumber : Data Primer Diolah, 2011

Dari hasil penelitian tersebut menuujukkan bahwa kontribusi pendapatan buruh sadap terhadap pendapatan keluarga sangat besar. Hal tersebut dikarenakan hanya sebagian kecil pendapatan keluarga yang berasal selain dari pendapatan buruh sadap. Kontribusi pendapatan di luar kegiatan menyadap karet berpengaruh nyata terhadap pendapatan total rumah tangga. Semakin besar kontribusi pendapatan dari luar kegiatan menyadap karet, maka akan semakin besar pula pendapatan total rumah tangga. Kondisi ini menunjukkan bahwa pekerjaan-pekerjaan di luar menyadap karet memiliki potensi yang besar untuk meningkatkan pendapatan rumah tangga. Semakin besar kontribusi pendapatan dari luar kegiatan penyadapan karet maka pendapatan total rumah tangga akan semakin besar pula. Pengamatan dilapangan menunjukkan bahwa para penyadap karet sebagian besar mengandalkan pendapatan keluarganya dari usaha menyadap karet. Pekerjaan-pekerjaan di luar menyadap karet dijadikan sebagai tambahan penghasilan. Sehingga peningkatan pendapatan yang berasal dari luar penyadapan karet akan memberikan dampak besar terhadap peningkatan pendapatan total rumah tangga. Kondisi ini dikarenakan peningkatan pendapatan dari penyadapan karet hanya dapat ditingkatkan dengan peningkatan produktivitas sadap dan itupun terbatas pada kemampuan pohon karet. 


\section{SIMPULAN DAN SARAN}

\section{Simpulan}

Berdasarkan hasil penelitian dapat diambil kesimpulan sebagai berikut:

1. Rata-rata produktivitas kerja buruh tani penyadap karet di desa air sekamanak sebesar 3,822 Kg/Jam. Hasil ini menunjukkan bahwa produktivitas kerja buruh sadap di desa Air Sekamanak sudah cukup baik. Tinggi rendahnya produktivitas kerja dipengaruhi oleh tingkat produksi. Produksi tanaman karet di pengaruhi oleh umur pohon karet, perlakuan pemupukan dan proses penyadapan.

2. Rata-rata pendapatan rumah tangga di desa air sekamanak sebesar Rp $1.946 .490,476 /$ Bln. Rata-rata pendapatan yang berasal dari buruh tani penyadap karet sebesar Rp 1.720.740,476/Bln dengan kontribusinya terhadap pendapatan rumah tangga sebesar $88,402 \%$. Sedangkan ratarata pendapatan yang berasal dari luar kegiatan menyadap karet sebesar Rp 225.750/Bln dengan kontribusinya terhadap pendapatan rumah tangga sebesar $11,598 \%$.

\section{Saran}

1. Perlu adanya pembinaan kemampuan dan keterampilan bagi pekerja buruh tani penyadap karet, sehingga dapat mengembangkan keterampilan yang lain. Dengan pengembangan usaha-usaha di luar penyadap karet dapat meningkatkan pendapatan dan mempersiapkan jika pemilik kebun karet memberhentikan kerja. Karena pekerjaan sebagai buruh tani penyadap karet tersebut bukan merupakan pekerjaan tetap yang dapat di jalankan dalam jangka panjang.

2. Usahatani karet Desa Air Sekamanak menguntungkan dan merupakan pekerjaan pokok. Untuk itu di harapkan kedepannya petani karet bisa lebih maksimal dalam penggunaan faktor produksi karena usahatani ini merupakan sumber pendapatan bagi petani dan buruh sadap karet.

3. Petani karet tidak menggunaan faktor produksi karena disebabkan harga faktor produksi yang tinggi dan masih sulitnya untuk memperoleh faktor produksi tersebut. Maka dari itu melalui program Pemerintah Daerah untuk bisa memberikan bantuan - bantuan berupa subsidi serta pembangunan sarana dan prasarana untuk kelancaran usahatani. 


\section{DAFTAR PUSTAKA}

Barani,Achmad M. 2008. Pedoman Umum Peremajaan Karet. Direktorat Jenderal Perkebunan. Jakarta

Dewi Sahara dkk,2004. Tingkat Pendapatan Petani Terhadap Komoditas Unggulan Perkebunan Sulawesi Tenggara. Balai Pengkajian Teknologi Pertanian (BPTP). Sulawesi Tenggara

Hamidum, 2007. Produktivitas Kerja. Copyright @ wordspress. com. (Diakses 13 november 2010)

Iskandar, 2002. Etos kerja, motivasi, dan sikap inovatif Terhadap produktivitas petani. Jurnal makara, sosial humaniora 6 (1) :26-29. Universitas Negeri Jakarta. Jakarta

Nasution Efrida. 2008. Analisis Produksi dan Tataniaga Karet Rakyat. Jurnal litbang pertanian. 1 (1) : 40-69. Medan

Nurmanaf, 2003. Peranan Sektor Non Pertanian Terhadap Pendapatan Rumah Tangga Petani Berlahan Sempit. Jurnal sosisal ekonomi pertanian 1(34): 294-298. Badan penelitian dan pengembangan pertanian. Jakarta

Soekartawi, 2002. Analisis Usaha Tani. Universitas Indonesia. Jakarta.

Umar Akmal, 2010. Peranan Upah, motivasi dan Kepuasan Dalam Meningkatkan Kinerja Perusahaan Maufaktur. Jurnal Peranan Upah, Motivasi Dan Kepuasan Pekerja 1 (1) : 1-8. Makasar

Wayan dan Suryadi, 2004. Ekonomi Tenaga Kerja Pertanian Dan Implikasinya Dalam Peningkatan Produksi Dan Kesejahteraan Buruh Tani Jurnal Litbang Pertanian 23 (3) : 91-99. Bogor

Widodo, S. 2003. Kerakteristik Penyadap Karet dan Hubunganya Dengan Produktivitas Skripsi. Jurusan Sosial Ekonomi Pertanian. Fakultas Pertanian. Universitas Bengkulu. Bengkulu (tidak dipublikasikan) 